\title{
THE EFFECT OF LIQUIDITY, PROFITABILITY, LEVERAGE ON CORPORATE VALUE WITH DIVIDEND POLICY AND BI RATE AS MODERATED VARIABLES (Study of Banking Companies Listed on the Indonesia Stock Exchange in 2014-2017)
}

\author{
Dana Eka Setiawan ${ }^{1}$ \\ Ika Yustina Rahmawati ${ }^{2}$ \\ Faculty of Economics and Business Universitas Muhammadiyah \\ Purwokerto
}

\begin{abstract}
This study aims to examine the effect of liquidity, profitability, leverage on corporate value with dividend policy and the BI Rate as a moderating variable on banking companies listed on the Indonesia Stock Exchange in 2014-2017. The study used a purposive sampling method for sampling, as many as 13 banks based on criteria. This study uses secondary data from company annual reports. Data were analyzed using SPSS 25. The results showed that: liquidity had a negative and not significant effect on corporate value, profitability had a positive and significant effect on corporate value, leverage had a negative and not significant effect on corporate value, dividend policy and the BI Rate are not able to moderate the effect of liquidity, profitability, and leverage on corporate value.
\end{abstract}

Keywords: Liquidity, Profitability, Leverage, Corporate Value, Dividend Policy, And The BI Rate.

\footnotetext{
1. 


\section{INTRODUCTION}

Banks are financial institutions whose main activities are collecting funds from the public in the form of deposits, current accounts and deposits as well as channeling funds to the public in the form of credit, and other forms of financial service products. At present the development and progress in the banking sector is very rapid, it is marked by the number of banks operating in Indonesia (Antoro \& Hermuningsih, 2018). According to RI Law No.10 Year 1998 the meaning of a bank is "a business entity that collects funds from the public in the form of deposits and distributes them to the public in the form of credit and / or other forms in order to improve the lives of many people."

The banking industry has a significant role in supporting economic growth and creating equity. The government and related stakeholders must coordinate with each other to ensure the direction of the policy being carried out on target. However, banking in Indonesia is faced with various problems. One of them is the 7-Day Reverse Repo Rate (7-DRRR) increase. Bank Indonesia (BI) has raised this benchmark interest rate by 75 basis points (bps). This increase in benchmark interest will affect the banking business. 7-DRRR will affect economic growth. Though economic growth greatly influences credit demand (CNBCIndonesia, 2018). Another problem is the management of liquidity. When looking at the banking intermediation ratio or loan to deposit ratio (LDR) almost all major banks face tight liquidity. The average banking LDR has reached $92 \%$. That is, the liquidity that can be managed by banks is only $8 \%$ of the total third party funds (CNBCIndonesia, 2018).

Company value is often associated with stock prices, where the higher the stock price of a company, the value of the company and the prosperity of shareholders will also increase. Price to Book Value (PBV) describes how much the market appreciates the book value of a company's stock. Companies that run well, generally have a PBV ratio above one, which reflects that the stock market value is greater than the book value. High PBV reflects the level of prosperity of shareholders, where the prosperity of shareholders is the main objective of the company (Ratnasari et al, 2017).

The first factor that can affect company value is liquidity. Liquidity is the company's ability to meet short-term financial obligations that can affect investment decisions for potential investors so that demand for company shares will increase and prices rise. In this study liquidity is proxied by Loan to Deposite Ratio (LDR). LDR is a 
liquid measure of the concept of inventory in the form of a ratio of loans to deposits (Antoro \& Hermuningsih, 2018).

Antoro \& Hermuningsih's research (2018) states that liquidity has a negative effect on firm value but the effect is not significant. Rochmah \& Fitria (2017) research on liquidity has a positive but not significant effect on firm value. Whereas in Fadhli's (2015) research, liquidity (LDR) significantly affected the value of the company.

The second factor that can affect the value of the company is profitability. The purpose of the company is to make a profit. The higher the level of profit obtained from total assets turnover, the company's ability to pay dividends will also be higher and the company's stock price will increase. The profitability ratio in this study uses a Return On Equity (ROE) proxy. In Antoro \& Hermuningsih's research (2018), the results of profitability have a significant positive effect on firm value supported by research by Rochmah \& Fitria (2017) and Sisca (2016). However, the results of research by Wulandari \& Wiksuana (2017) stated that profitability had a significant negative effect on firm value.

The third factor that can affect the value of a company is the debt or leverage ratio. Leverage is used to measure a company's ability to meet all financial obligations consisting of short-term debt and long-term debt. By looking at previous research that Debt to Asset Ratio (DAR) has no significant effect, in this study the researchers tried to use another leverage proxy that is Debt to Equity Ratio (DER) which is a comparison of the number of long-term loans owned by companies with their own capital. In Antoro and Hermuningsih's research (2018) leverage has a positive effect on firm value but the effect is not significant. However, the results of the research by Rochmah \& Fitria (2017) leverage have a significant negative effect on firm value.

The fourth factor is dividend policy, dividend policy is a decision to divide profits to shareholders as dividends or will hold in the form of retained earnings to be used as investment financing in the future (Antoro \& Hermuningsih, 2018). In Antoro and Hermuningsih's research (2018) dividends have a significant positive effect on firm value. In contrast to the research of Fauziah and Asandimitra (2018) dividend policy on firm value has no positive or negative influence. 
Another important factor that cannot be ignored is looking at macroeconomic conditions. From a macroeconomic perspective, what affects stock returns is the interest rate on Bank Indonesia Certificates (SBI). The BI Rate is the reference rate or basis for banks in Indonesia in setting the interest rates for savings products and loans that they will offer to their prospective customers (www.bi.go.id). In Antoro and Hermuningsih's research (2018) the BI Rate has a negative effect on firm value but the effect is not significant.

Whereas in the research of Ningsih and Waspada (2019) the BI Rate has a significant and positive influence on firm value. In this regard, the writer wants to know the effect of liquidity, profitability, leverage on firm value with dividend policy and the BI Rate as a moderating variable. This research is a replication of the research conducted by Antoro and Hermuningsih (2018), because the results from previous researchers are inconsistent so that further research is needed. The difference between this research and previous research is to change the proxy of leverage and firm value.

Based on the background description of the problem, the researcher wants to conduct a study entitled "THE EFFECT OF LIQUIDITY, PROFITABILITY, LEVERAGE ON CORPORATE VALUES WITH CORPORATE DIVIDEND POLICY AND BI RATE AS VARIABLE MODERATION Studies on Banking Companies Listed on the Stock Exchange in 2014-2017".

\section{THEORETICAL BACKGROUND}

\section{A. Liquidity}

According to Fred Weston in Kasmir (2018: 129), liquidity is the company's ability to meet its short-term obligations in a timely manner. Or in other words, liquidity is that which shows the ability of a company to pay its short-term debts (liabilities) that are due, or to determine the company's ability to finance and fulfill obligations (debt) when billed (Kasmir, 2018: 110). Liquidity ratios at banks according to Kasmir (2018: 221) are as follows: (a) Quick Ratio, (b) Investing Policy Ratio, (c) Banking Ratio, (d) Asset to Loan Ratio, (e) Investment Portfolio Ratio, ( f) Cash Ratio, (g) Loan to Deposit Ratio. In this study liquidity is proxied by LDR (Loan to Deposit Ratio). LDR is a ratio used to measure the composition of the amount of credit given compared to the amount of public funds and own capital used (Kasmir, 2018: 225). 


\section{B. Profitability}

Profitability is a ratio that illustrates a company's ability to generate profits. The better the profitability ratio, the better the ability to describe the high profitability of the company (Fahmi, 2014: 80). Profitability ratios that can be used are: (a) Profit Margin on Sales, (b) Return on Investment, (c) Return on Equity, (d) Earnings Per Share of Common Stock (Earning per Share of Common Stock). In this research, profitability is projected using Return On Equity (ROE), ROE ratio serves to measure the amount of profit that can be generated by using capital owned or show the effectiveness and efficiency of the company in generating profits using capital resources from investors.

\section{Leverage}

Leverage is a ratio used to measure how much a company is financed with debt. The use of high debt is dangerous for the company because the company will be included in the category of extreme leverage (Fahmi, 2014: 72). According to Kasmir (2018: 155) the types of leverage ratios are: (a) Debt to Asset Ratio, (b) Debt to Equity Ratio, (c) Long Term Debt to Equity Ratio (LTDtER), (d) Times Interest Earned, (e) Fixed Charge Coverage. In this study leverage is proxied by Debt to Equity Ratio (DER). This ratio is often used by analysts and investors to see how much the company's debt compared to the equity owned by the company or shareholders.

\section{Dividend Policy}

Dividend policy is a decision taken by a company related to dividends, whether the profits earned will be shared with investors in the form of dividends or the profits will be retained as retained earnings for investment financing in the future. According to Gumanti (2013: 41) there are five commonly known theories, namely: the theory of irrelevant dividend (irrelevant dividend proposition theory), smoothing theory, the theory of bird in the hand (bird in the hand theory), the theory of tax effects (tax effect theory), client dividend effect theory (client effect theory). In this study dividend policy is proxied by the Dividend Payout Ratio (DPR). 


\section{E. BI Rate}

Based on the Bank Indonesia website (www.bi.go.id), the BI Rate is a policy interest rate that reflects the stance or monetary policy stance adopted by Bank Indonesia and is announced to the public. Bank Indonesia in general will raise the BI Rate if future inflation is estimated to exceed the target set. Based on Bank Indonesia circular No.8 / 13 / DPM concerning the issuance of Bank Indonesia Certificates, are securities in rupiah currency issued by Bank Indonesia in recognition of short-term debt.

\section{F. The Value of The Company}

The company's value in this study is defined as the market value of a company's stock. Market value is the prevailing share value in the market. This value is determined by the strength of supply and market demand for company shares. The value of the company can provide maximum prosperity for shareholders if the company's stock price increases. The value of the company is a positive signal for investors, that the high value of the company reflects the prosperity of holding shares is also high (Sisca, 2016). There are several indicators to measure company value including: price to earnings ratio, price to book value, and Tobin's Q. This study uses PBV indicators to measure firm value. PBV is a comparison between market price per share and book value per share (Suryantini \& Arsawan, 2014; Brigham \& Houston, 2013 in Fuad \& Wandari, 2018).

\section{G. Framewrok}

1. Effect of Liquidity on Company Value

According to Kasmir (2018: 225) Loan to Deposit Ratio (LDR) is a ratio that is used to measure the composition of the amount of credit given compared to the amount of public funds and own capital money used. The safe limit of a bank's LDR is around $80 \%$. However, the maximum LDR limit according to the government is $110 \%$. Research on the effect of liquidity on firm value has been investigated by Mery (2017) with the result that liquidity has an effect on firm value, supported by research by Fadhli (2015). The results of the study indicate that the higher the liquidity, the higher the company's value and the lower the liquidity, the lower the company's value. High cash capability will have an impact on the ability of the company's short-term liabilities and have a positive impact on the value of the company. 
H1: Liquidity has a positive and significant effect on firm value.

\section{Effect of Profitability on Company Value}

According to Kasmir (2018: 114) profitability is the ability of companies to look for profits or profits in a certain period. And also provides a measure of the level of management effectiveness of a company which is shown from profits generated from sales or from investment income. Research on the effect of profitability on firm value has been investigated by Antoro and Hermuningsih (2018) with the results of profitability having a significant positive effect on firm value, supported by Puspitaningtyas (2017) and other researchers. High profitability can provide added value to the value of the company which is reflected in the stock price.

$\mathrm{H} 2$ : Profitability has a positive and significant effect on firm value.

\section{Effect of Leverage on Company Value}

According to Kasmir (2018: 113) defines that the Solvency Ratio is the ratio used to measure the extent to which a company's assets are financed with debt. Leverage in this study is represented by Debt to Equity Ratio (DER). Debt to Equity Ratio reflects the ability of a company's equity to cover medium and long term obligations. Research on the influence of leverage on firm value has been investigated by Rochmah \& Fitria (2017) leverage has a significant negative effect on firm value. The size of the shortterm or long-term debt owned by the company is not given much attention by investors, because investors look more at how the company's management uses these funds effectively and efficiently to achieve added value to the company's value.

H3: Leverage has a negative and significant effect on firm value.

\section{The Effect of Dividend Policy on Liquidity Relationships to Firm Value}

Liquidity illustrates the ability of a company to meet its financial obligations that must be met immediately. Liquidity will affect the size of the dividends paid to shareholders. Dividends are cash outflows, the greater the amount of cash available, the better the company liquidity is, the greater the company's ability to pay dividends (Harjito and Martono, 2001 in Mery, et al 2017). 
In research Mery (2017) dividend policy is able to moderate liquidity to the value of the company. Supported by Fadhli (2015) and Mery (2017) research that liquidity is moderated by dividend policy has a significant influence on firm value. Dividend policy can increase company value when liquidity is high and dividend policy can decrease company value when liquidity is low.

H4: Dividend policy is able to moderate the effect of liquidity on company value.

\section{Effect of Dividend Policy on Profitability Relationships to Firm Value}

Company value can be seen from the company's ability to pay dividends. The amount of this dividend can affect stock prices. If the dividend paid is high, the stock price tends to be high so the value of the company is also high. Company profitability can also affect the distribution of dividends to investors. High profitability affects investor decisions in the value of the company.

In the research of Rochmah \& Fitria (2017) dividend policy is able to significantly moderate the effect of profitability on firm value. Supported by research by Fadhli (2015) and Mery (2017) dividend policy is able to moderate profitability on firm value. Dividend policy can increase company value when profitability is high and dividend policy can decrease company value when profitability is low.

H5: Dividend policy is able to moderate the effect of profitability on firm value.

\section{The Effect of Dividend Policy on the Leverage Relationship to Firm Value}

Company value can be seen from the company's ability to pay dividends. The amount of this dividend can affect stock prices. If the dividend paid is high, the stock price tends to be high so the value of the company is also high. Good corporate leverage management can return company assets and can earn profits to be distributed as dividends to investors.

Previous research by Antoro and Hermuningsih (2018) leverage which is moderated by dividends has no significant effect on firm value, supported by research by Fadhli (2015). Dividend policy can increase company value when leverage is high and dividend policy can increase company value.

H6: Dividend policy is able to moderate the effect of leverage on firm value. 


\section{Effect of BI Rate on Liquidity Relationships Against Firm Value}

BI Rate is a policy interest rate that reflects the stance or monetary policy stance adopted by Bank Indonesia and announced to the public (www.bi.go.id). Liquidity illustrates the ability of a company to meet its financial obligations that must be met immediately. The smooth liquidity can affect the value of the company which will attract potential investors. In a previous study by Antoro and Hermuningsih (2018) stated that liquidity moderated by the BI Rate had no significant effect on firm value.

H7: BI Rate is able to moderate the effect of liquidity on company value.

\section{Effect of BI Rate on Profitability Relationships to Firm Value}

When many prospective customers who are interested will increase the profitability of the bank so that it can affect the value of the company in the eyes of investors. In the results of Meiviana's research (2018) interest rates as a moderating variable strengthen the relationship between profitability and firm value.

H8: BI Rate is able to moderate the effect of profitability on firm value.

\section{Effect of BI Rate on Leverage Relationships on Firm Value}

The BI Rate that benefits companies can help banking companies to pay off corporate leverage to return assets and generate profits. In previous research by Antoro and Hermuningsih (2018) the leverage moderated by the BI Rate had no significant effect on firm value.

H9: BI Rate is able to moderate the effect of leverage on firm value.

\section{METHOD, DATA AND ANALYSIS}

This type of research is a quantitative research method. Quantitative research is research that uses data in the form of numbers or qualitative data that is framed / scoring (Sugiyono, 2014: 28). The population of this study is the banking companies listed on the Indonesia Stock Exchange (IDX) in the study period 2014 to 2017. The sample is part of the number and characteristics possessed by the population. In determining the sample the researcher used a purposive sampling method, namely the technique of determining the sample with certain considerations (Sugiyono, 2014: 149). Banking companies that meet the sampling criteria amounted to 13 companies from 43 general 
banking companies.

In this study the method of data collection is done through literature studies in the form of journals, previous research, and supported by other supporting literature and secondary data obtained from financial reports and annual reports of banking companies listed on the Indonesia Stock Exchange which have been published in www.idx.co .id. Data analysis was performed by multiple linear regression analysis. Before testing the hypothesis, it is first performed with the classic assumption test that is normality test, multicollinearity test, and heteroscedasticity test. And test the suitability of the regression model. The following is an operational definition of this research:

Table 1

Definition of Variable Operations

\begin{tabular}{|c|c|c|}
\hline No. & Variable & Formula \\
\hline 1 & Liquidity & Total Loan \\
\hline 2 & Profitability & $\begin{array}{c}\text { Earning After Interest and Tax } \\
\text { EDF }\end{array}$ \\
\hline & & Equity \\
\hline 3 & Leverage & $\mathrm{DER}=\frac{\text { Total Debt }}{}$ \\
\hline 4 & Dividend Policy & DPR $=\frac{\begin{array}{c}\text { Total Equity } \\
\text { Dividen per Share }\end{array}}{\text { Earning per Share }}$ \\
\hline 5 & BI Rate & End of year interest rates \\
\hline 6 & $\begin{array}{l}\text { The Value of The } \\
\text { Company }\end{array}$ & $\mathrm{PBV}=\frac{\text { Harga per Lembar Saham }}{\text { Nilai Buku per Lembar Saham }}$ \\
\hline
\end{tabular}

\section{Multiple Linear Regression Analysis}

In this study, multiple linear regression analysis is used to determine whether there is an influence of independent variables, namely liquidity, profitability, leverage on the dependent variable firm value and using standardized values as variables (absolute difference value) as a moderation test to determine whether there is an influence of moderating variables dividend policy and BI Rate with independent variables are liquidity, profitability and leverage on the dependent variable of firm value. The regression equation model with standardized values as variables in this study is as follows:

$$
\begin{aligned}
& \mathrm{Y}=\mathrm{a}+\beta 1 \mathrm{XX} 1+\beta 2 \mathrm{ZX} 2+\beta 3 \mathrm{ZX} 3+\beta 4|\mathrm{ZX} 1-\mathrm{ZZ1}|+\beta 5|\mathrm{ZX} 2-\mathrm{ZZ1}|+\beta 6|\mathrm{XX} 3-\mathrm{ZZ1}|+
\end{aligned}
$$

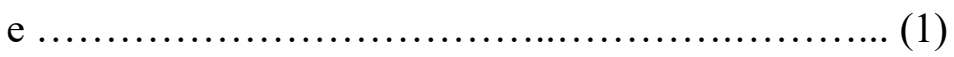

$$
\begin{aligned}
& \mathrm{Y}=\mathrm{a}+\beta 1 \mathrm{ZX} 1+\beta 2 \mathrm{ZX} 2+\beta 3 \mathrm{ZX} 3+\beta 4|\mathrm{ZX} 1-\mathrm{ZZ2}|+\beta 5|\mathrm{ZX} 2-\mathrm{ZZ2}|+\beta 6|\mathrm{ZX} 3-\mathrm{ZZ2}|+
\end{aligned}
$$


e

\section{RESULTS AND DISCUSSION}

\section{Multiple Regression Analysis}

Regression results that show the effect of independent variables on the dependent variable with moderation variables can be seen in tables below

\section{Table 2.}

Equation Multiple Linear Regression Test Results 1

\begin{tabular}{|c|c|c|c|c|c|c|}
\hline \multicolumn{7}{|c|}{ Coefficients $\mathrm{s}^{\mathrm{a}}$} \\
\hline \multirow{2}{*}{\multicolumn{2}{|c|}{ Model }} & \multicolumn{2}{|c|}{$\begin{array}{l}\text { Unstandardized } \\
\text { Coefficients }\end{array}$} & \multirow{2}{*}{$\begin{array}{l}\text { Standardized } \\
\text { Coefficients } \\
\text { Beta }\end{array}$} & \multirow[b]{2}{*}{$\mathrm{T}$} & \multirow[b]{2}{*}{ Sig. } \\
\hline & & $\mathrm{B}$ & Std. Error & & & \\
\hline 1 & (Constant) & 1.527 & .186 & & 8.190 & .000 \\
\hline & $\begin{array}{l}\text { Zscore: } \\
\text { LDR }\end{array}$ & -.154 & .114 & -.166 & -1.346 & .185 \\
\hline & $\begin{array}{l}\text { Zscore: } \\
\text { ROE }\end{array}$ & .485 & .167 & .516 & 2.904 & .006 \\
\hline & $\begin{array}{l}\text { Zscore: } \\
\text { DER }\end{array}$ & -.231 & .152 & -.245 & -1.523 & .135 \\
\hline & LDR_DPR & -.046 & .171 & -.048 & -.268 & .790 \\
\hline & ROE_DPR & .232 & .206 & .200 & 1.130 & .265 \\
\hline & DER_DPR & .013 & .204 & .013 & .062 & .951 \\
\hline
\end{tabular}

a. Dependent Variable: PBV

Based on the results of the regression analysis above, a regression equation can be arranged as follows:

$\mathrm{Y}=\mathrm{a}+\beta 1 \mathrm{ZX} 1+\beta 2 \mathrm{ZX} 2+\beta 3 \mathrm{ZX} 3+\beta 4|\mathrm{ZX} 1-\mathrm{ZZ1}|+\beta 5|\mathrm{ZX} 2-\mathrm{ZZ1}|+\beta 6|\mathrm{ZX} 3-\mathrm{ZZ1}|+\mathrm{e}$ $\mathrm{Y}=1,527-0,154 \mathrm{ZX} 1+0,485 \mathrm{ZX} 2-0,231 \mathrm{ZX} 3-0,046|\mathrm{ZX} 1-\mathrm{ZZ} 1|+0,232|\mathrm{ZX} 2-\mathrm{ZZ} 1|+$ $0,013|Z X 3-Z Z 1|+e$ 
Table 3.

Equation Multiple Linear Regression Test Results 2

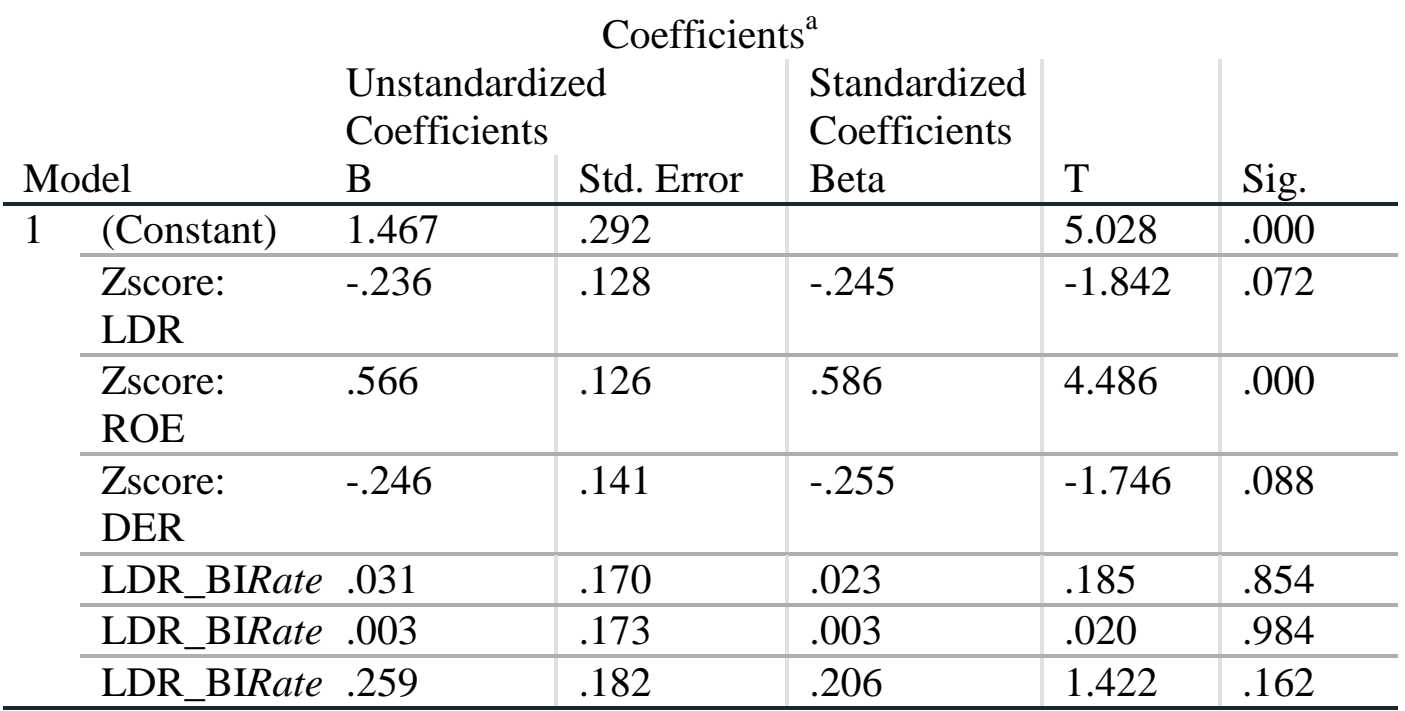

a. Dependent Variable: PBV

Based on the results of the regression analysis above, a regression equation can be arranged as follows:

$\mathrm{Y}=\mathrm{a}+\beta 1 \mathrm{ZX} 1+\beta 2 \mathrm{ZX} 2+\beta 3 \mathrm{ZX} 3+\beta 4|\mathrm{ZX} 1-\mathrm{ZZ} 2|+\beta 5|\mathrm{ZX} 2-\mathrm{ZZ2}|+\beta 6|\mathrm{ZX} 3-\mathrm{ZZ} 2|+\mathrm{e}$ $\mathrm{Y}=1,467-0,236 \mathrm{ZX} 1+0,566 \mathrm{ZX} 2-0,246 \mathrm{ZX} 3+0,031|\mathrm{ZX} 1-\mathrm{ZZ} 2|+0,003|\mathrm{ZX} 2-\mathrm{ZZ} 2|+$ $0,259|Z X 3-Z Z 2|+e$

\section{Determination Coefficient Test}

The adjusted R Square value of the regression model formed in this study is 0.386 which indicates that the ability of independent variables (liquidity, profitability, leverage), standardize liquidity variables are moderated by dividend policy standardize, standardize profitability variables are moderated by standardize dividend policy and standardize leverage is moderated by standardize dividend policy in explaining the dependent variable (company value) is $38.6 \%$ and the remaining $61.4 \%$ is influenced by other variables not included in the study.

The adjusted R Square value of the regression model formed in this study is 0.278 which shows that the ability of independent variables (liquidity, profitability, leverage), standardize liquidity variables are moderated by the BI Rate, standardize profitability variables are moderated by the BI Rate and the standardized leverage variables are moderated by standardize BI Rate in explaining the dependent variable (company value) 
is $27.8 \%$ and the remaining $72.2 \%$ is influenced by other variables not included in the study.

\section{Hypothesis Test / t Test}

\section{A. Effect of liquidity on firm value}

Based on the partial hypothesis test results show that liquidity has a negative and not significant effect on firm value. This result is proved by -t count> -t table (-1.334> 1.681 ) and a significant value of $0.185>0.05$. The results of this study indicate that the LDR has a negative and not significant effect, which means that any increase in LDR will reduce the value of the company. With a high LDR, the credit to be disbursed is also high even though the loan that is disbursed is very high, it will bring profits to the company, but the possibility of uncollectible debts is also high so the company's value will also decrease. In other words, the higher the LDR shows the more risky condition of bank liquidity, conversely the lower the LDR shows the lack of effectiveness of banks in lending. Thus the bank is expected to be able to maximize the value of the company and still maintain bank liquidity ratios at a healthy level.

The results of this study are in line with the research of Antoro and Hermuningsih (2018) which states that liquidity has a negative and not significant effect on firm value. However, the results of this study are not in line with the research of Putra \& Lestari (2017) which states that liquidity has a positive and significant effect on firm value.

\section{B. Effect of profitability on firm value}

Based on the partial hypothesis test results show that profitability has a positive and significant effect on firm value. This result is proved by t count> t table (2.904> $1.681)$ and a significant value of $0.006<0.05$. Profitability (ROE) shows the level of net profit that can be achieved by the company when running its operations. Bank profits that are worth sharing with shareholders are profits after interest and taxes, so that with high profitability (ROE) can provide added value to the value of the company which is reflected in the price of its shares. The ability to generate profits will be responded positively by investors, one of which is reflected in an increase in share prices.

The results of this study are in line with research by Antoro and Hermuningsih (2018), Rochmah \& Fitria (2017) and Putra \& Lestari (2016) which states that 
profitability has a significant positive effect on firm value. However, the results of this study are not in line with the research of Wulandari \& Wiksuana (2017) which states that profitability is not a significant negative effect on firm value.

\section{The effect of leverage on the value of the company}

Based on the partial hypothesis test results show that leverage has a negative and not significant effect on firm value. This result is proved by -t count <-t table $(-1.523<-$ 1.681 ) and a significant value of $0.135>0.05$. For banks (creditors), the greater this ratio, the more unprofitable because the greater the risk borne by the failure that may occur in the company. For companies, the greater the ratio, the better, in contrast to the low ratio, the higher the level of funding provided by the owner and the greater the safety limit for the borrower in the event of loss or depreciation of the value of the asset.

This result is in line with Sisca's research (2016) which states that leverage does not have a significant negative effect on firm value. But it is not in line with the research by Rochmah \& Fitria (2017) which states that leverage has a significant negative effect on firm value and on the results of Wulandari \& Wiksuana (2017) research which states that leverage has a positive and significant effect on firm value.

\section{The effect of dividend policy as a moderation in the relationship of liquidity to the value of the company}

Based on partial hypothesis test results show that dividend policy is not able to moderate the effect of liquidity on firm value. This result is proven by - $t$ count $>-t$ table ($0.268>-2.017)$ and a significant value of $0.790>0.025$. Dividend policy as a moderating variable is stated to not significantly moderate the relationship between liquidity and firm value. This condition also illustrates that dividend payments carry at least a negative effect on bank liquidity because with the existence of cash dividend payments the bank issues large amounts of cash. Therefore the results of the moderating variable test results in insignificant negative effect.

The results of this study are supported by Antoro and Hermuningsih (2018) and Rochmah \& Fitria (2017) research which states that dividend policy is not able to significantly moderate the effect of liquidity on firm value. The study is not in line with research conducted by Fadhli (2015) which states that liquidity is moderated by dividend 
policy has a significant effect on firm value and Mery (2017) research states that dividend policy is able to moderate liquidity to firm value.

\section{E. The effect of dividend policy as a moderation in the relationship of profitability to the value of the company}

Based on the partial hypothesis test results show that dividend policy is not able to moderate the effect of profitability on firm value. This result is proven by $t$ count $<\mathrm{t}$ table $(1.130>2.017)$ and a significant value of $0.265>0.025$. Dividend policy distributed by bank companies which is used as a moderating variable is stated unable to significantly moderate the relationship between profitability and firm value. Dividend policy is not able to strengthen the value of the company when bank profitability is not healthy, and dividend policy is also not able to reduce the value of the company when bank profitability is very healthy.

The results of this study are in line with the research of Anantoro \& Hermuningsih (2018) and Puspitaningtyas (2017) which states that dividend policy is not able to moderate profitability on firm value. But in research Mery (2017) dividend policy is able to moderate profitability to the value of the company and Fadhli (2015) states that the return of assets moderated by dividend policy has a significant influence on the value of the company.

\section{F. The effect of dividend policy as a moderation in the relationship of leverage on firm value}

Based on partial hypothesis test results show that dividend policy is not able to moderate the effect of leverage on firm value. This result is proved by $t$ count $<t$ table $(0.062>2.017)$ and a significant value of $0.951>0.025$. Dividend policy distributed by bank companies which is used as a moderating variable is stated to not be able to moderate the relationship between leverage and firm value significantly. Dividend policy is not able to strengthen the value of the company when the leverage of the bank is not healthy, and the dividend policy is also not able to reduce the value of the company when the leverage of the bank is very healthy. This result is in line with the research of Anantoro \& Hermuningsih (2018) and Mery (2017) which states that dividend policy is not able to moderate leverage on firm value. But it is not in line with the research of 
Rochmah \& Fitria (2017) dividend policy is able to significantly moderate the effect of leverage on firm value.

\section{G. The effect of the BI Rate as a moderation in the relationship of liquidity to the value of the company}

Based on the partial hypothesis test results show that the BI Rate is not able to moderate the effect of liquidity on firm value. This result is proved by $t$ count $<\mathrm{t}$ table $(0.185>2.014)$ and a significant value of $0.854>0.025$. BI Rate as a moderating variable is stated unable to moderate the relationship between liquidity and firm value significantly. The BI Rate that has been set by Bank Indonesia is not able to strengthen the value of the company when the company's liquidity is not healthy, and the BI Rate is also unable to reduce the value of the company when the company's liquidity is very healthy. This result is in line with the research of Anantoro and Hermuningsih (2018) which states that liquidity moderated by the BI Rate has no significant effect on firm value.

\section{H. The effect of the BI Rate as a moderation in the relationship of profitability to firm value}

Based on partial hypothesis test results show that the BI Rate is not able to moderate the effect of profitability on firm value. This result is proved by $t$ count $<\mathrm{t}$ table $(0.020>2.014)$ and a significant value of $0.984>0.025$. BI Rate as a moderating variable cannot significantly influence the profitability of firm value. BI Rate that has been set by Bank Indonesia is not able to strengthen the value of the company when company profitability is not healthy, and the BI Rate is also not able to reduce the value of the company when the profitability of the company is very healthy. This result is in line with the research of Anantoro and Hermuningsih (2018) which states that profitability moderated by the BI Rate has no significant effect on firm value. But not in line with the study of Meivinia (2018) interest rates as a moderating variable strengthens the relationship between profitability and firm value. 


\section{The effect of the BI Rate as a moderation in the relationship of leverage to firm value}

Based on partial hypothesis test results show that the BI Rate is not able to moderate the effect of leverage on firm value. This result is proved by $t$ count $<t$ table $(1.422>2.014)$ and a significant value of $0.162>0.025$. BI Rate as a moderating variable cannot significantly influence the leverage of the firm's value. BI Rate that has been set by Bank Indonesia is not able to strengthen the value of the company when the leverage of the company is not healthy, and the BI Rate is also unable to reduce the value of the company when the leverage of the company is very healthy. This result is in line with the research of Anantoro and Hermuningsih (2018) which states that the leverage that is moderated by the BI Rate has no significant effect on firm value.

\section{CONCLUSIONS}

The aim of this research is to provide empirical evidence of the influence of independent variables, namely liquidity, profitability and leverage on the dependent variable, namely the value of the company with the moderating variable dividend policy and the BI Rate. Based on the analysis that has been done, the following conclusions can be drawn:

1. Liquidity has a negative and not significant effect on company value.

2. Profitability has a positive and significant effect on firm value.

3. Leverage has a negative and not significant effect on firm value.

4. Dividend policy is not able to moderate the effect of liquidity on company value.

5. Dividend policy is not able to moderate the effect of profitability on company value.

6. Dividend policy is not able to moderate the effect of leverage on firm value.

7. BI Rate is not able to moderate the effect of liquidity on company value.

8. BI Rate is not able to moderate the effect of profitability on company value.

9. BI Rate is not able to moderate the effect of leverage on firm value.

Research Limitations

1. There are several banking companies that did not distribute dividends during the study period.

2. The sample used in this study is only 52 data, so it does not rule out the possibility that different results will be obtained if using more samples. 
3. Data must be casewised so that data can be normally distributed

4. Data must use the method of absolute difference (standardized value as variables) to avoid multicollinearity.

5. Data must be transformed to prevent heteroscedasticity

\section{IMPLICATIONS}

1) For Investors

Can be used as a reference and be taken into consideration in making investments so that the feasibility analysis of stock investments can be more accurate. Investors should pay attention to the financial performance of banking companies, especially profitability and dividend policies. The higher the profitability and dividend payments, the future prospects of the company will be better and its value will increase.

2) For Companies

The company is expected to be able to maximize existing resources and pay attention to factors that can affect the value of the company. Because the company's value is taken into consideration for investors in investing.

3) For Academics and Further Researchers

To increase the number of company samples and increase the period of research for better results. And this research can be a reference for further research. It is better to replace the proxy for the measurement of each variable in order to avoid high multicollinearity values.

\section{REFERENCES}

Antoro, D. A., \& Hermuningsih, S. 2018. Kebijakan Dividen dan BI Rate Sebagai Pemoderasi Likuiditas, dan Leverage Terhadap Nilai Perusahaan Perbankan yang Terdaftar Di BEI. Upajiwa Dewantara, 2(1), 58-75.

Asandimitra, A. F. dan N. 2018. Pengaruh keputusan investasi, keputusan pendanaan, kebijakan dividen, dan profitabilitas terhadap nilai perusahaan (studi pada perusahaan industri dasar dan kimia yang terdaftar di bei periode tahun 20122016), 6(2011).

Fadhli, M. 2015. Pengaruh Likuiditas, Solvabilitas Dan Profitabilitas Terhadap Nilai Perusahaan Dengan Kebijakan Dividen Sebagai Variabel Moderasi Pada Perusahaan Perbankan, Asuransi \& Lembaga Keungan Lainnya Di Bursa Efek Indonesia Tahun 2010-2013. Jom FEKON, 2(2), 1-14.

Fahmi, Irham. 2014. Manajemen Keuangan Perusahaan dan Pasar Modal. Jakarta : Mitra Wacana Media. 
Fauziah, A., \& Asandimitra, N. 2018. Pengaruh Keputusan Investasi, Keputusan Pendanaan, Kebijakan Dividen, Dan Profitabilitas Terhadap Nilai Perusahaan (Studi Pada Perusahaan Industri Dasar Dan Kimia Yang Terdaftar Di BEI Periode Tahun 2012-2016). Jurnal Ilmu Manajemen, 6(3), 84-92.

Fuad, M., \& Wandari, A. 2018. Pengaruh Struktur Modal dan Faktor Eksternal terhadap Nilai Perusahaan (Studi pada PT. Bank Central Asia, Tbk). Jurnal Manajemen Dan Keuangan, 7(1), 32-46.

Gumanti, T.A. 2013. Kebijakan Dividen : Teori, Empiris dan Implikasi. Yogyakarta: UPP STIM YKPN.

Kasmir. 2018. Analisis Laporan Keuangan. Depok: PT RajaGrafindo Persada.

Meiviana, L. 2018. Pengaruh Likuiditas, Profitabilitas, Struktur Modal, dan Suku Bunga Terhadap Nilai Perusahaan. Jurnal Muara Ilmu Ekonomi dan Bisnis. Vol.2, No.2:380-393.

Mery, K.N. 2017. Pengaruh Likuiditas, Leverage Dan Profitabilitas Terhadap Nilai Perusahaan Dengan Kebijakan Dividen Sebagai Variabel Moderasi Pada Perusahaan Pertambangan Yang Terdaftar Di Bursa Efek Indonesia Tahun 20112014. JOM Fekon, 4(1), 2000-2014.

Ningsih, M.M., dan Waspada, I. 2019. Pengaruh Suku Bunga, Struktur Modal, dan Ukuran Perusahaan Terhadap Nilai Perusahaan: Studi Empiris Pada Perusahaan Di Indonesia. Jurnal Riset Akuntansi dan Keuangan, 7 (1), 2019, 97-110.

Puspitaningtiyas, Z. 2017. Efek Moderasi Kebijakan Dividen Dalam Pengaruh Profitabilitas Terhadap Nilai Perusahaan Manufaktur. Jurnal Akuntansi, Ekonomi dan Manajemen Bisnis Article History. Vol. 5, No. 2, 173-180.

Putra, N.D., \& Lestari, P.V. 2016. Pengaruh Kebijakan Dividen, Likuiditas, Profitabilitas, dan Ukuran Perusahaan Terhadap Nilai Perusahaan. E-Jurnal Manajemen Unud, Vol. 5, No.7, 2016: 4044 - 4070.

Ratnasari, S., Tahwin, M., \& Sari, D. A. 2017. Pengaruh Keputusan Investasi, Keputusan Pendanaan, Kebijakan Dividen dan Profitabilitas Terhadap Nilai Perusahaan Manufaktur Sektor Industri Barang Konsumsi yang Terdaftar Di Bursa Efek Indonesia. Buletin Bisnis \& Manajemen, 03(01), 80-94.

Rochmah, S.A., \& Fitria, A. 2017. Pengaruh Kinerja Keuangan Terhadap Nilai Perusahaan : Kebijakan Dividen Sebagai Variabel Moderating. Jurnal Ilmu dan Riset Akuntansi, 6(3), 998-1017.

Sisca. 2016. Pengaruh Leverage Dan Profitabilitas Terhadap Nilai Perusahaan Dengan Kebijakan Dividen Ssebagai Variabel Moderating Pada Perusahaan Manufaktur Yang Terdaftar Di Bursa Efek Indonesia Tahun 2010 - 2014. Jurnal SULTANIST, 4(1), 1-9.

Sugiyono. 2014. Metode Penelitian Manajemen. Bandung: Alfabeta.

Wulandari, N.M.I \& Wiksuana, I.G.B. 2017. Peranan Corporate Social Responsbility Dalam Memoderasi Pengaruh Profitabilitas, Leverage, dan Ukuran Perusahaan Terhadap Nilai Perusahaan. E-Jurnal Manajemen Unud, Vol. 6, No. 3 :12781311.A

WwW.cnbcindonesia.com

www.idx.co.id 